\title{
DECAY RESISTANCE OF WOOD IMPREGNATED WITH MONOETHANOLAMINE AND SODIUM BISULFITE PULPING BLACK LIQUORS
}

\author{
Hamid Reza Nayeri ${ }^{1}$, Asghar Tarmian ${ }^{2, \star}$, Ali Abdulkhani $^{2}$, Ghanbar Ebrahimi $^{3}$
}

\begin{abstract}
The efficacy of monoethanolamine and sodium bisulfite pulping black liquors at three concentrations of $1 ; 1,5$ and $2 \%$ on the preservation of poplar wood from white rot (Trametes versicolor) was investigated. The wood specimens were impregnated with the black liquors using a full-cell method. The black liquors enhanced the decay resistance without any reduction in mechanical strength, and a remarkable increase was observed at higher concentrations and weight gain percentage. The performance of monoethanolamine black liquor was more pronounced, probably due to lower kappa number and higher $\mathrm{pH}$. The durability class of specimens impregnated with $2 \%$ monoethanolamine and sodium bisulfite black liquors improved from 5 (not durable) to 1 (very durable), and from 5 to 3 (moderately durable), respectively. Chemical analysis showed that the presence of additional lignin in wood alters the white rot. Results of anatomical studies showed that the fibers of the control and impregnated wood specimens were collapsed after 16 weeks of incubation. Leaching tests confirmed that the fixation of black liquors in wood should be examined for further studies.
\end{abstract}

Keywords: Chemical analysis, mechanical strength, Populus nigra, pulping properties, Trametes versicolor, wood preservation.

\section{INTRODUCTION}

Besides many benefits of timber, its susceptibility to biological degradation, like fungal decay limits it for exterior construction. The decay resistance of wood depends on several factors such as the species of wood, its moisture content and chemical composition (e.g. the extractive content), climatic conditions and its intended use (Delucis et al. 2016, Fidah et al. 2016). Therefore, it needs to be protected from biodegradation using chemical preservatives. Oil-borne or waterborne preservatives are usually used to enhance the wood service life. Chemical wood preservation is one of the main industries during its processing. For example, the annual gross sales of preserved wood were about $\$ 3,91 \times 10^{9}$ in USA in 1996 (Hingston et al. 2001). However, recent environmental concerns about the toxicity of some common heavy metal based preservative products like chromated copper arsenate (CCA) have stimulated researchers to find alternatives (Hill et al. 2004, Mai and Militz 2004).

Natural durability of some durable wood species like pine confined to the heartwood is attributed to their extractives (Schmidt 2006).

\footnotetext{
${ }^{1}$ MSc graduated, Department of Wood and Paper Science \& Technology, Faculty of Natural Resources, University of Tehran, Karaj, Iran. nayeri_hamid@yahoo.com

${ }^{2}$ Associate professor, Department of Wood and Paper Science \& Technology, Faculty of Natural Resources, University of Tehran, Karaj, Iran. abdolkhani@ut.ac.ir

${ }^{3}$ Professor, Department of Wood and Paper Science \& Technology, Faculty of Natural Resources, University of Tehran, Karaj, Iran. ibrahimi@ut.ac.ir

"Corresponding author: tarmian@ut.ac.ir
}

Received: 04.09.2016 Accepted: 18.08.2017 
Black liquor of pulp and paper mills is a complex aqueous solution, comprising organic materials from the raw materials (dissolved lignin, carbohydrates and resinous compounds of a low molar mass) and the inorganic chemicals (mainly soluble salt ions) used in the process (Cardoso et al. 2009). The chemical composition of black liquor depends on the type of the raw material used and pulping conditions. Approximately 7 tonnes of black liquor are produced in the manufacture of one tonne of pulp (Biermann 1993). 39-54\% of solid content of Kraft black liquor and 55\% of sulfite black liquor were composed from lignin (Sjöström 1993). However, the lignin separation process from black liquors is troublesome and expensive and requires a lot of energy (Sjöström 1993). Thus, only around 1 to 2\% of this lignin is used to make other products because of the problems (Lora and Glasser 2002). Most modern pulp mills burn the liquor in order to recover the cooking chemicals and utilize the heat value of the organic material (Jönsson et al. 2008). The recovery process of black liquor in sodium bisulfite pulping is depicted in Figure 1. Despite many studies regarding the role of black liquor in energy production, the utility of this waste product as a wood preservative is largely unexplored (Durmaza et al. 2015).

The potential biocide effect of some lignin derivatives and Kraft black liquor was previously reported (Durmaza et al. 2015, Chirkova et al. 2012, Iulian et al. 2011).

Bagasse is a by-product of sugarcane fiber left after juice extraction. It is one of the most available fibrous raw materials for pulp and paper production in some countries, such as China, Brazil, Iran and India. For example, about 4,3 million tons of bagasse is annually produced in Iran (Samariha and Khakifirooz 2011). The chemical composition of bagasse varies according to the variety of sugarcane and harvesting method. The main chemical compositions of bagasse plant fibers are cellulose (45$55 \%$ ), hemicellulose (20-25\%), lignin (18-24\%), pectin (0,6-0,8\%), ash (1-4\%) and extractives $(1,5-9 \%)$ (Yadav et al. 2015). In this study, the potential use of bagasse pulping black liquors from monoethanolamine (MEA) and sodium bisulfite pulping processes was evaluated for poplar wood protection from Trametes versicolor which is one of naturally abundant timber rot fungi.

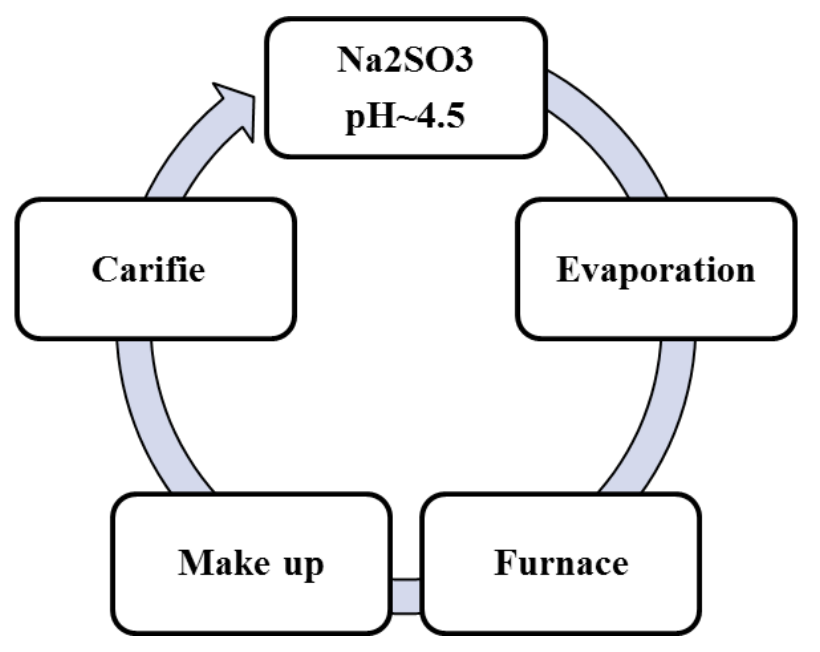

Figure 1. Recovery of black liquor in sodium bisulfite pulping.

\section{MATERIALS AND METHODS}

\section{Pulping and preparation of black liquors}

Bagasse prepared from Haft Tapeh, Ahvaz in Iran was used for pulping. Two different pulping processes, sodium bisulphite and monoethanolamine (MEA) were applied. The pulping conditions are 
given in Table 1 . Sulfuric acid with $98 \%$ purity was used to acidify the solution to $\mathrm{pH} 5$. Kappa number for each pulping process was also measured using equation $1: \mathrm{k}=(\mathrm{p} \times \mathrm{f}) / \mathrm{w}$ according to TAPPI Standard No. 236 om- 99 where $\mathrm{p}=[(\mathrm{b}-\mathrm{a}) \times \mathrm{N}] / 0,1 ; \mathrm{k}$ is Kappa number, $\mathrm{F}$ is factor for correction to a $50 \%$ permanganate consumption, dependent on the value of $\mathrm{p}$ (Table 2), $\mathrm{w}$ is weight of moisture-free pulp in the specimen $(\mathrm{g}), \mathrm{p}$ is amount of $0,1 \mathrm{~N}$ permanganate actually consumed by the test specimen $(\mathrm{mL}), \mathrm{b}$ is amount of the thiosulfate consumed in the blank determination $(\mathrm{mL})$, $a$ is amount of the thiosulfate consumed by the test specimen $(\mathrm{mL}), \mathrm{N}$ is normality of the thiosulfate. Factors in Table 2 are based on the equation $2: \log \mathrm{k}=\log \mathrm{p} / \mathrm{w}+0,00093(\mathrm{p}-50)$. The black liquors were dissolved in water to reduce the viscosity and to make solutions at three concentrations of 1; 1,5 and 2\% (dry solids) for wood impregnation.

Table 1. Monoethanolamine (MEA) and sodium bisulfite pulping conditions.

\begin{tabular}{|l|c|c|}
\hline Pulping parameters & $\begin{array}{c}\text { Mo o o th a n o l a m in e } \\
\text { (MEA) }\end{array}$ & Sodium bisulfite \\
\hline The charge of bagasse, OD, $g$ & 100 & 100 \\
\hline MEA/water $(\%)$ & $75: 25$ & - \\
\hline Sulfite $(\%)$ & - & 20 \\
\hline Solid/liquid ratio & $1: 6$ & $1: 6$ \\
\hline Cooking temperature $\left({ }^{\circ} \mathrm{C}\right)$ & 160 & 160 \\
\hline Time (min) & 90 & 180 \\
\hline pH of black liquor & $10,6(0,26)$ & $5,1(0,25)$ \\
\hline Kappa number & 15 & 39 \\
\hline
\end{tabular}

Table 2. Factors $f$ to correct for different percentages of permanganate used.

\begin{tabular}{|c|c|c|c|c|c|c|c|c|c|c|c|}
\hline $\mathbf{P}$ & + & $\mathbf{0}$ & $\mathbf{1}$ & $\mathbf{2}$ & $\mathbf{3}$ & $\mathbf{4}$ & $\mathbf{5}$ & $\mathbf{6}$ & $\mathbf{7}$ & $\mathbf{8}$ & $\mathbf{9}$ \\
\hline 30 & & 0,958 & 0,960 & 0,962 & 0,964 & 0,966 & 0,968 & 0,970 & 0,973 & 0,975 & 0,977 \\
\hline 40 & & 0,975 & 0,981 & 0,983 & 0,985 & 0,987 & 0,989 & 0,991 & 0,994 & 0,966 & 0,998 \\
\hline 50 & & 1,000 & 1,002 & 1,004 & 1,006 & 1,009 & 1,011 & 1,013 & 1,015 & 1,017 & 1,019 \\
\hline 60 & & 1,022 & 1,024 & 1,026 & 1,028 & 1,030 & 1,033 & 1,035 & 1,037 & 1,039 & 1,042 \\
\hline 70 & & 1,044 & & & & & & & & & \\
\hline
\end{tabular}

\section{Preparation and impregnation of test wood blocks}

Samples from poplar sapwood (Populus nigra) were prepared with dimensions of $50 \times 15 \times 25$ $\mathrm{mm}$ at moisture content of $12 \%$. Before impregnation, they were end coated by paraffin to prevent the black liquor penetration in the longitudinal direction, and to find how easily the liquors can penetrate through the transverse direction. A full-cell method was applied to achieve complete impregnation of all porous spaces of wood. The specimens were first put in a vessel and vacuum of $60 \mathrm{kPa}$ was then applied for 20 minutes. Finally, black liquors as treating solutions were allowed to flow in the vessel and the specimens remained submerged at pressure of $300 \mathrm{kPa}$ for 120 minutes.

\section{Measuring impregnation parameters}

Retention of black liquors $(\mathrm{R})$ in the wood specimens ( $\mathrm{kg}$ of black liquor per $\mathrm{m}^{3}$ of wood) was measured by equation 3: $\mathrm{R}=\left[\left(\mathrm{M}_{2}-\mathrm{M}_{1}\right) / \mathrm{V}\right] \times \mathrm{C} / 100$ where $M_{2}$ is the mass of sample after impregnation $(\mathrm{kg}), M_{1}$ is the mass of sample before impregnation $(\mathrm{kg}), V$ is the volume of sample $\left(\mathrm{m}^{3}\right)$ and $C$ is the concentration of black liquor (wt. \%). Weight gain percentage (WPG) of specimens (\%) due to absorbed black liquors was calculated by equation 4 : WPG $=\left[\left(\mathrm{W}_{2}-\mathrm{W}_{1}\right) / \mathrm{W} 1\right] \times 100$ where $W_{2}$ is oven dry weight of impregnated sample $(\mathrm{kg}), W_{1}$ is oven dry weight of sample before impregnation $(\mathrm{kg})$. The impregnated samples were air dried for 3 days and then put in a conditioning room at $20^{\circ} \mathrm{C}$ and $65 \% \mathrm{RH}$ for 2 weeks to allow the fixation of black liquors in wood. The specimens were cross cut by means of a cross cut saw to determine the penetration depth of black liquors. A leaching test was also performed according to EN 84 standard. For this test, the oven dried samples with dimensions of 50 $\times 15 \times 25 \mathrm{~mm}^{3}$ were first impregnated with distillated water, and subsequently the leaching water was 
decanted and replaced with the fresh one for nine times over a period of 14 days using a wood/water volume ratio of 1:5. Finally, the sample weight reduction was measured as a leaching indicator.

\section{Decay test}

Wood specimens with dimensions of 15 (radial) $\times 25$ (tangential) $\times 50$ (longitudinal) $\mathrm{mm}$ were used for decay test. First, they were oven dried at $103^{\circ} \mathrm{C}$ for $24 \mathrm{~h}$ and sterilized in an autoclave at $121^{\circ} \mathrm{C}$, $1500 \mathrm{kPa}$ for $20 \mathrm{~min}$. Then, the sterilized specimens were exposed to Trametes versicolor (a white-rot fungus) in petri dishes containing malt extract agar medium according to EN 113. 4 replicates were used for each treatment. After incubation at $25^{\circ} \mathrm{C}$ and $85 \% \mathrm{RH}$ for 16 weeks, the specimens were isolated, cleaned of mycelia by scalpel, dried at $103^{\circ} \mathrm{C}$ for $24 \mathrm{~h}$ and weighted. The mass loss (ML) was calculated with equation 4: $\mathrm{ML}(\%)=100 \times\left(\mathrm{m}_{1}-\mathrm{m}_{2}\right) / \mathrm{m}_{1}$ where $\mathrm{m}_{1}$ is the initial dry mass of sample before exposure to fungus, and $\mathrm{m}_{2}$ is the dry mass after exposure to fungus. The classification of wood durability was carried out by using the mass loss data according to CEN/TS 15083-1.

\section{Measuring mechanical properties}

Mechanical properties of control samples and those impregnated by black liquors with $2 \%$ concentration were measured. Modulus of elasticity (MOE) and modulus of rupture (MOR) tests was performed according to ISO-3349 and ISO-3133, respectively. Impact bending and compression strength parallel to grain (CSPG) were also measured according to D-143 ASTM standard. An INSTRON testing machine (XI series, Model 4486) was used to measure MOE, MOR and CSPG. Impact bending strength was measured by an AMSLER testing machine. 10 replicates were used for each treatment.

\section{Chemical and cell wall changes after decay}

Lignin and holocellulose contents of specimens treated with 2\% MEA black liquor were measured before and after exposure to T. versicolor in comparison with those of control sample. Air-dried samples were ground in Willey mill to pass a 40 mesh screen. The lignin and holocellulose contents of wood flour extracted with acetone were measured according to TAPPI 222 om- 88 and T9 wd-75 standards, respectively. Acetone-soluble extractive content of the specimens was also measured based on T $280 \mathrm{pm}-99$ standard. Three replicates were conducted for each treatment. The intensity of cell wall degradation for untreated- and 2\% MEA liquor treated-wood was characterized using a light microscope. Transverse sections of 10-15 $\mu \mathrm{m}$ in thickness were cut with a sliding microtome close to the sample surfaces as much as possible. After staining of sections with safranin, the microscopic observations were conducted at $100 \mathrm{x}$ magnification.

\section{Statistical analyses}

Statistical analysis was performed with SPSS software. Average values of groups were compared by one-way ANOVA analysis and Duncan test at the significance level of 5\%.

\section{RESULTS AND DISCUSSION}

\section{Decay resistance}

Both MEA and sodium bisulfite black liquors improved the wood resistance to the white rot fungus (Figure 2). The mass loss caused by T. versicolor in 2\% MEA liquor-treated wood was below 5\%, while the untreated wood showed a mass loss of $32,8 \%$. The samples treated with bisulfite black liquor showed less decay resistance to T. versicolor compared to MEA liquor-treated samples. The mass loss of MEA liquor-treated wood ranged from 3,9-21,3\% compared with 17,3-29,9\% for bisulfite liquortreated wood. The fungal resistance improved by increasing the black liquor concentration from 1 to $2 \%$. 


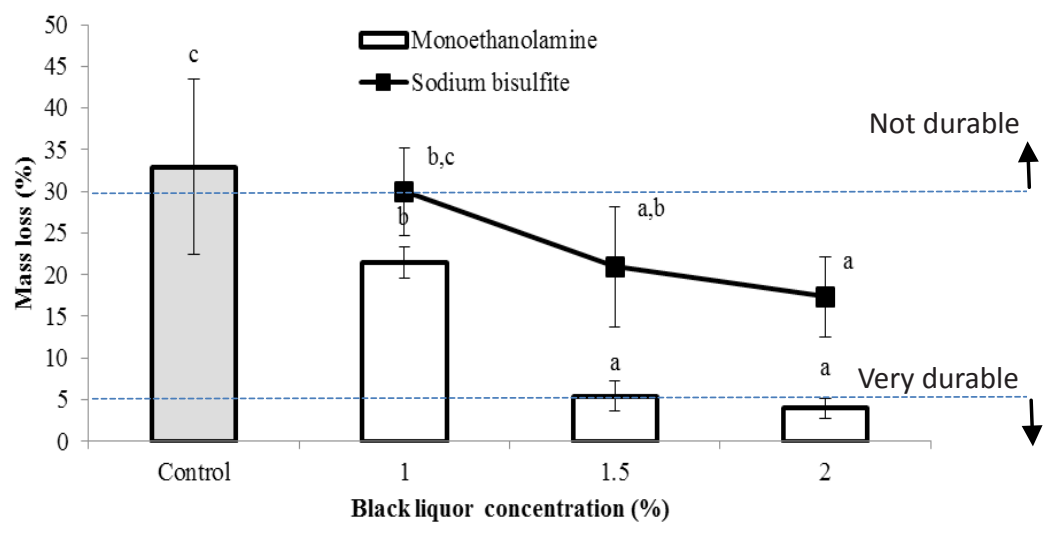

Figure 2. Mass loss of impregnated and control specimens exposed to Trametes versicolor.

Kappa number of monoethanolamine pulp was 15 compared to 39 for sodium bisulfite pulp, indicating a high percentage of lignin in the MEA black liquor (Table 1). In other words, pulping with MEA process is more selective in the lignin degradation. Thus, higher fungal resistance of wood specimens impregnated by MEA black liquor is probably due to the presence of greater pure lignin and less carbohydrates in the liquor. Another reason can be attributed to higher $\mathrm{pH}$ of MEA black liquor (Table 1). The rate of fungal growth depends on $\mathrm{pH}$ of wood. Wood with a high $\mathrm{pH}$ may have a high durability. The optimum $\mathrm{pH}$ range for growth of T. versicolor was reported to be 4 6 (Jo et al. 2010). The $\mathrm{pH}$ of MEA black liquor ranged from 10 to 11 that are unsuitable for growing white rot fungi. It has been reported that some fungicides such as various phenols are distinctly more toxic when applied as high $\mathrm{pH}$ alkali metal phenates than when applied as phenols (Richardson 1993). The durability class of specimens impregnated with 2\% MEA and sodium bisulfite black liquors improved from 5 (not durable) to 1 (very durable) and from 5 to 3 (moderately durable), respectively. Durmaz et al. (2015) also found that Kraft black liquor enhanced the durability of Scots pine sapwood exposed to brown rot fungus (Coniophora puteana and Poria Placenta). The authors reported a mass loss less than $3 \%$ for the treated samples. The samples treated with bisulfite black liquor showed less WPG compared to MEA liquor-treated samples (Figure 3a). The difference was more pronounced at higher concentrations. For both black liquors, the WPG increased by increasing the liquor concentration. As can be seen in "fungal mass loss vs. WPG" curve (Figure 3b), there is a correlation between the WPG and fungal mass loss in the black liquor treated specimens (Figure $3 \mathrm{~b}$ ). The decay resistance improved by increasing the WPG. Reduction in the mass loss was 1,8 and $2,02 \%$ mass loss $/ \%$ WPG for specimens treated by MEA and sodium bisulfite liquors, respectively.

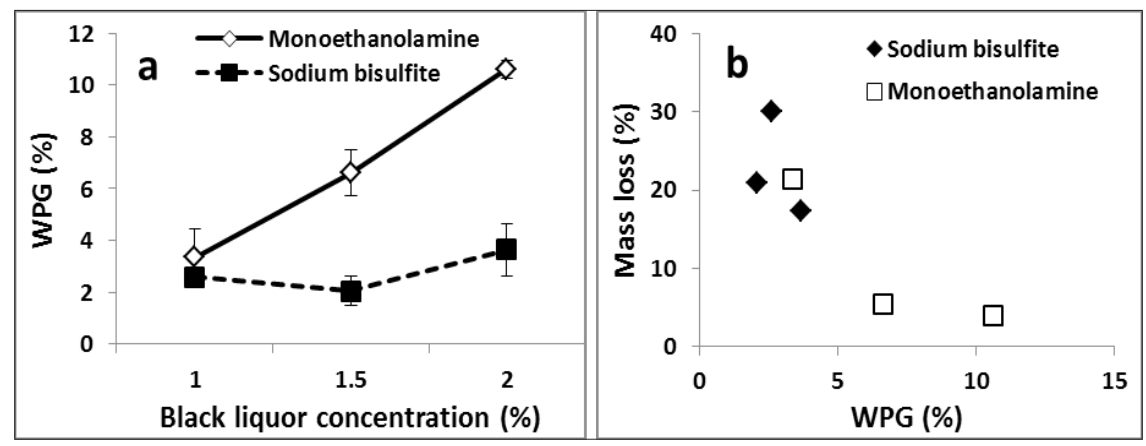

Figure 3. a) Weight gain percentage (WPG) of specimens after impregnation with black liquors at different concentrations; b) Fungal mass loss vs. WPG. 
In terms of fungal decay resistance, the poplar wood treated by both black liquors has a potential application for categories of UC1 and UC2 for interior construction (AWPA 2006). Examples for UC1 category are interior furniture and millwork and those for UC2 are interior beams, timbers, flooring, framing and millwork (AWPA 2006). The wood treated by MEA black liquor had a light gray color, whereas the color of wood remained almost unaffected after impregnation with sodium bisulfite black liquor. Both treated wood had a clean surface and no odor after drying. The liquors also had no effect on the natural appearance of the wood.

\section{Retention}

All black liquor solutions completely penetrated to the test specimens. The retention value ranged from 6,3 to $15,2 \mathrm{~kg} . \mathrm{m}^{-3}$. The maximum retention was recorded when wood blocks were impregnated with 2\% MEA black liquor (Figure 2). The retention was also raised as the black liquor concentration increased. Similar effects of preservative concentration on its retention in wood have been reported in previous studies (Pan et al. 2015). A proper amount of preservative must be absorbed in wood to provide adequate toxicity. The preservative concentration together with the impregnation time and the combined effects of these parameters determine the retention. Minimum requirements for preservative retention vary by preservative, wood species, potential for decay and its intended use. For use in extreme hazard situations like marine piles, a high net retention is required. In the case of a waterborne salt preservative, typically 4 to $28 \mathrm{~kg} / \mathrm{m}^{3}$ is achieved depending on the preservative involved and the purpose for which the treatment is intended (Richardson 1993). For example, the lowest retention value of CCA $\left(4 \mathrm{~kg} / \mathrm{m}^{3}\right)$ is required for above ground applications and the highest value $\left(40 \mathrm{~kg} / \mathrm{m}^{3}\right)$ is intended for saltwater applications (AWPA 2006). The retention values required for Alkaline copper quaternary (ACQ) are $2,4 \mathrm{~kg} / \mathrm{m}^{3}$ for above ground use and $6,4 \mathrm{~kg} / \mathrm{m}^{3}$ for ground contact (AWPA 2006). Thus, the retention values obtained by all black liquor solutions should be high enough for interior construction (the use classes of UC1 and UC2).

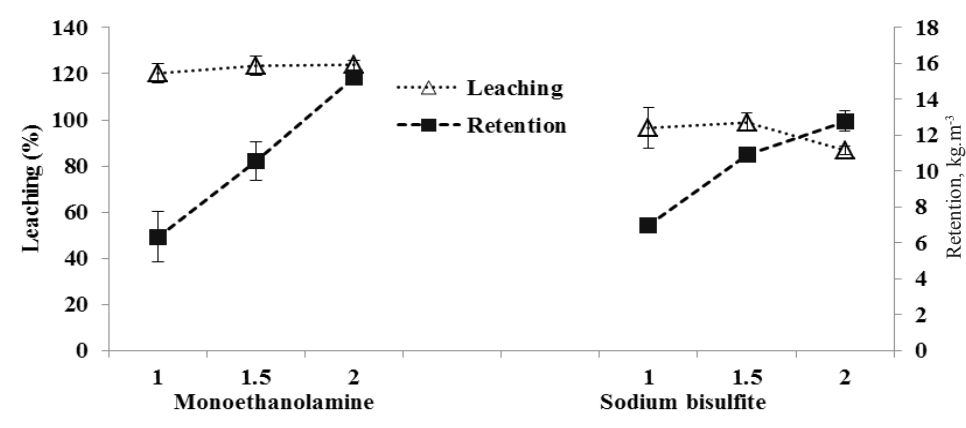

Black liquor concentration $(\%)$

Figure 4. Leaching and retention properties of poplar wood impregnated by monoethanolamine (MEA) and sodium bisulfite black liquors with concentrations of 1, 1,5 and 2\% .

\section{Leaching of black liquors}

Leaching tests showed that both black liquors were washed away entirely from the test specimens (Figure 4). Some leaching may be related to removal of wood extractive materials. The leaching rate was almost similar for all three concentrations of MEA black liquor. In contrast, the leachability of sodium bisulfite black liquor reduced by increasing its concentration from 1,5 to $2 \%$. Borate compounds such as Disodium octaborate tetrahydrate (DOT) and Boric acid are environmentally friendly and relatively cheap waterborne preservatives which are widely used for protection of wood against fungal decay and insect attacks. Similar to the black liquors, borates can leach from treated wood and thus they should be used only for applications where the wood is protected from wetting. The minimum retention required for borates is $2,7 \mathrm{~kg} / \mathrm{m}^{3}$ and a higher retention $\left(4,5 \mathrm{~kg} / \mathrm{m}^{3}\right)$ is commercially needed for protection against termites (AWPA 2006). 
The leaching resistance of a wood preservative is obtained by the chemical fixation reactions. However, the fixation of preservatives in wood usually needs a complex process. The mechanism for the fixation reactions depends on the type of wood preservative. A number of strategies can be applied to reduce waterborne preservatives leaching such as use of other chemicals to produce less leachable compounds, coating, addition of hydrophobic agents and combination of the preservatives and vegetable oils (Lyon et al. 2007). The methods mentioned above are recommended for further investigation to reduce the leaching of black liquors. Reduction in the leaching rate of some common wood preservative components by increasing the concentration of impregnation solutions was also reported in previous studies (Pizzi 1983). In addition to environmental exposures, the impregnation conditions may affect the leaching rates of preservatives. Post-treatment drying conditions may affect the leachability of preservative components. The accelerated fixation by using high temperatures instead of ambient ones may increase the leaching rate (Eaton and Hale 1993). The use of black liquortreated wood for exterior construction, such as decking and foundation piling is limited due to the leaching. However, to apply a treated wood for outdoor construction, a number of other properties like weathering resistance and bondability should be evaluated in addition to the biological resistance.

\section{Mechanical properties}

As shown in Table 3, the impregnation of specimens with both black liquors had no negative effect on MOR, MOE and impact bending strengths. However, the compression strength parallel to grain (CSPG) was slightly reduced (around 7,6 \%) after impregnation with MEA black liquor, probably due to its high $\mathrm{pH}$ value. A high $\mathrm{pH}$ value of 10-11 may degrade the lignin and hemicellulose of wood. Thus, it can be stated that the CSPG of wood is probably more sensitive to its lignin content. The CSPG of tropical wood species was also reported to be higher than that of temperate regions due to the higher percentage of lignin (Ebrahimi 1997). Although the impregnation of wood specimens with black liquors had no significant effect on the mechanical strengths, longterm effect of such preservatives needs to be evaluated.

Table 3. Mechanical properties of control specimens and those impregnated by $2 \%$ monoethanolamine (MEA) and sodium bisulfite black liquors.

\begin{tabular}{|c|c|c|c|c|c|c|c|c|}
\hline \multirow[t]{3}{*}{ Wood specimen } & \multirow{2}{*}{\multicolumn{2}{|c|}{$\begin{array}{c}\begin{array}{c}\text { Modulus of } \\
\text { elasticity (MOE) }\end{array} \\
\mathrm{MPa}\end{array}$}} & \multirow{2}{*}{\multicolumn{2}{|c|}{$\begin{array}{c}\begin{array}{c}\text { Modulus of } \\
\text { rupture (MOR) }\end{array} \\
\mathrm{MPa}\end{array}$}} & \multirow{2}{*}{\multicolumn{2}{|c|}{$\begin{array}{c}\text { Impact bending } \\
\mathrm{MPa}\end{array}$}} & \multirow{2}{*}{\multicolumn{2}{|c|}{$\begin{array}{c}\text { Compression } \\
\text { strength parallel to } \\
\text { grain (CSPG) } \\
\mathrm{J} / \mathrm{m}^{2}\end{array}$}} \\
\hline & & & & & & & & \\
\hline & Mean & SD & Mean & SD & Mean & SD & Mean & SD \\
\hline Control & 7858,2 & 884,1 & 69,3 & 8,6 & 50276,3 & 9672,7 & 49,1 & 4,2 \\
\hline $\begin{array}{l}\text { MEA-liquor treated } \\
\text { wood }\end{array}$ & 7382,7 & 633,8 & 67,5 & 6,3 & 46842,7 & 13179,7 & 45,6 & 3,02 \\
\hline $\begin{array}{l}\text { Bisulfite liquor- } \\
\text { treated wood }\end{array}$ & 7680,9 & 421,9 & 72,1 & 3,9 & 53587,1 & 16103,4 & 49,7 & 2,8 \\
\hline
\end{tabular}

\section{Changes in cell wall chemistry and anatomy}

Holocellulose content of untreated wood specimens exposed to the fungus reduced by $21,3 \%$. No significant difference was found in the holocellulose content between control (unexposed) and MEA black liquor-treated wood (Figure 5). After fungal exposure, the lignin content of wood specimens impregnated by MEA black liquor decreased by around $48 \%$. This high reduction in lignin content is probably due to the existence of monoethanolamine in the liquor. Simultaneous white-rot fungi such as $T$. versicolor simultaneously degrade lignin, cellulose, and hemicelluloses, while selective whiterot fungi, which lack the ability to degrade cellulose efficiently, cause extensive delignification of wood (Fackler and Schwanninger 2012). Thus, it can be stated that the presence of additional lignin in wood alters the white rot. It was also claimed that white-rot fungi must degrade the lignin to gain access to the polysaccharides of wood (Highley Terry 1982). Extractive content for unexposed control wood specimens ranged from 1,06 to $2,3 \%$. No changes were observed in the extractive content of untreated specimens after fungal exposure. Extractive content for specimens impregnated by $2 \%$ MEA black liquor was three times greater than that of untreated wood. Dissolving of alkali soluble wood 
components such as lignin into the extract under monoethanolamine at $\mathrm{pH}$ of $10-11$ can be possible reason for the increased extractive content.

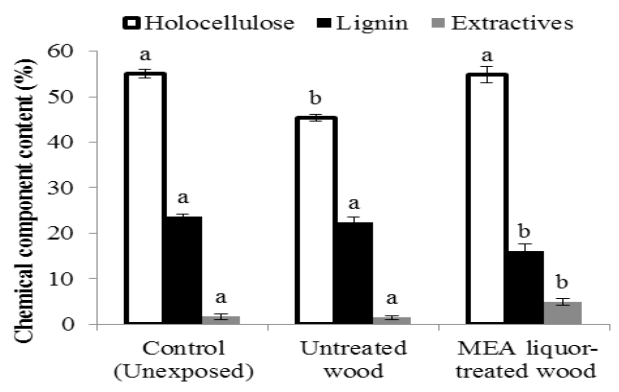

Figure 5. The residual holocellulose, lignin and extractive contents of decayed untreated- and MEA black liquor-treated wood compared to the control wood.

Although the fugal hyphae can be seen in the fiber lumina (Figure 6a, arrow), no remarkable damage occurred in the specimens treated with MEA-black liquor. Untreated wood showed eroded and thinned cell walls after fungal exposure. Collapsing of cell walls was evident in untreated and treated wood specimens incubated by the fungus.

In contrast to the black liquor-treated wood, the surfaces of untreated wood were almost completely covered by the hyphae after 16 weeks of incubation (Figure 6d, Figure 6f).

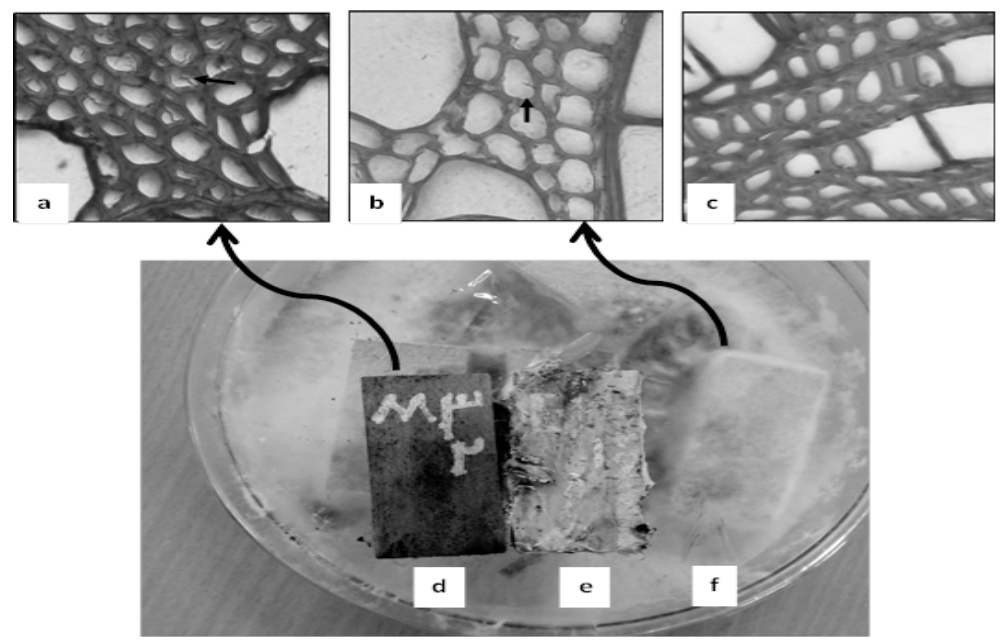

Figure 6. Microscopic images of MEA liquor treated- (a) and untreated-samples (b) after exposure to T. versicolor for 16 weeks in comparison with the unexposed control sample (c), Magnification 100 $\mathrm{x}$; fungal hyphae in the fiber lumina (a, arrow); MEA liquor treated- (d), sodium bisulfite treated- (e) and untreated (f) wood blocks.

\section{CONCLUSIONS}

The potential use of monoethanolamine (MEA) and sodium bisulfite black liquors was evaluated to improve the poplar wood resistance to white-rot fungus ( $T$. versicolor). On the whole, the wood impregnation by both black liquors can be considered as an approach to improve its fungal resistance without any reduction in the mechanical strengths. Durability class of poplar wood improved from 5 (not durable) to 1 (very durable) after impregnation with 2\% MEA black liquor. However, the main concern for such preserved wood is leaching of black liquors from wood for outdoor construction. Therefore, black liquor-treated wood is limited to applications like building framing subjected to dampness with low leaching rate. Otherwise, further investigation is recommended to study on the 
fixation of black liquors in wood. Although the mechanical strengths of treated woods were not affected by the black liquors, it is questionable whether such impregnation processes have no negative impacts on the wood strength for long-term use.

\section{REFERENCES}

ASTM. American Society for Testing and Materials. 1994. Standard Test Methods for Small Clear Specimens of Timber. ASTM D 143.

AWPA. American Wood-Preservers' Association Standard. 2006. Use Category System.

Biermann, J. 1993. Essentials of Pulping and Papermaking. Academic Press, San Diego.

Cardoso, M.; Oliveira, E.D.; Passos, M.L. 2009. Chemical composition and physical properties of black liquors and their effects on liquor recovery operation in Brazilian pulp mills. Fuel 88: 756-763.

CEN/TS. 2006. Durability of wood and wood-based products, Determination of the natural durability of solid wood against wood-destroying fungi, Test methods, Part 1: Basidiomycetes. CEN/ TS 15083-1.

Chirkova, J.; Anderson, I.; Irbe, I.; Spince, B.; Andersons, B. 2012. Lignin as agents for bioprotection of wood. Holzforschung 65: 497-502.

Delucis, R. D. A.; Cademartori, P. H.G.; Missio, A. L.; Gatto, D.A. 2016. Decay resistance of four fast-growing Eucalypts wood exposed to three types of fields. Maderas-Cienc Tecnol 18(1): 33-42.

Durmaza, S.; Erisirb, E.; Yildiza, U.C.; Kurtulusab, O.C. 2015. Using Kraft Black Liquor as A Wood Preservative. Procedia - Social and Behavioral Sciences 195: 2177-2180.

Eaton, R.A.; Hale, M.D.C. 1993. Wood: Decay, Pests, and Protection. Chapman and Hall, London.

Ebrahimi, G. 1997. Mechanical strength of wood and its elements and analysis of rocking composite laminate of wood. University of Tehran Press, Tehran.

European Committee for Standardization EN 113. 1996. Wood preservatives, Test method for determining the protective effectiveness against wood destroying basidiomycetes, Determination of the toxic values, Brussels.

European Committee for Standardization EN 84. 1996. Wood preservatives, Accelerated ageing of treated wood prior to biological testing, Leaching procedure, Brussels.

Fackler, K.; Schwanninger, M. 2012. How spectroscopy and microspectroscopy of degraded wood contribute to understand fungal wood decay. Applied Microbiology and Biotechnology 96: 587599.

Fidah, A.; Salhi, N.; Rahouti, M.; Kabouchi, B.; Ziani, M.; Aberchane, M.; Famiri, A. 2016. Natural durability of cedrus Atlantica wood related to the bioactivity of its essential oil against wood decaying fungi. Maderas-Cienc Tecnol 18(4):567-576.

Highley Terry, L. 1982. Influence of type and amount of lignin on decay by Coriolus versicolor. Canadian Journal of Forest Research 12: 435-438.

Hill, C.A.S.; Farahani, M.R.M.; Hale, M. D. C. 2004. The use of organo alkoxysilane coupling agents for wood preservation. Holzforschung 58: 316-325.

Hingston, J.A.; Collins, C.D.; Murphy, R.J.; Lester, J.N. 2001. Leaching of chromated copper 
arsenate wood preservatives: a review. Environmental Pollution.111: 53-66.

International Organization for Standardization (ISO) 3133. 1975. wood-determination of ultimate strength in static bending.

International Organization for Standardization (ISO) 3349. 1975. Wood -Determination of modulus of elasticity in static bending.

Iulian-Andrei, S.G.; Adina-Mirela, C.; Silviagrama Popa, V.I. 2011. Agents for wood bioprotection based on natural aromatic compounds and their complexes with copper and zinc. Cellulose Chemistry and Tehnology 45: 227-231.

Jo, W.S.; Kang, M.J.; Choi, S.Y.; Yoo, Y.B.; Seok, S.J.; Jung. H.Y. 2010. Culture conditions for mycelia growth of Coriolus versicolor. Mycobiology 38: 195-202.

Jönsson, A.; Nordin, A.; Wallberg, O. 2008. Concentration and purification of lignin in hardwood kraft pulping liquor by ultrafiltration and nanofiltration. Chemical Engineering Research and Design 86: $1271-1280$.

Lora, J. H.; Glasser, W.G. 2002. Recent industrial applications of lignin: A sustainable alternative to nonrenewable materials. Journal of Polymers and the Environment 10: 39-48.

Lyon, F.; Thevenon, M.F.; Hwang, W.J.; Imamura, Y.; Gril, J.; Pizzi, A. 2007. Effect of an oil heat treatment on the leachability and biological resistance of boric acid impregnated wood. Annals of Forest Science 64 (6): 673-678.

Mai, C.; Militz H. 2004. Modification of wood with silicon compounds, Treatment systems based on organic silicon compounds - a review. Wood Science and Technology 37: 453-461.

Pan, C.; Ruan, G.; Chen, H.; Zhang, D. 2015. Toxicity of sodium fluoride to subterranean termites and leachability as a wood preservative. European Journal of Wood and Wood Products 73: $97-102$.

Pizzi, A. 1983. Practical Consequences of the Clarification of the Chemical Mechanism of CCA Fixation to Wood (IRG/WP/3220). The International Research Group on Wood Preservation, Stockholm.

Richardson, B.A. 1993. Wood preservation. Taylor \& Francis, London.

Samariha, A.; Khakifirooz, A. 2011. Application of NSSC pulping to sugarcane bagasse. BioResources 6(13): 3313-3323.

Schmidt, O. 2006. Wood and Tree Fungi: Biology, Damage, Protection, and Use. Springer, Berlin.

Sjöström, E. 1993. Wood Chemistry Fundamentals and Applications. Academic Press, San Diego.

Technical Association of the Pulp and Paper Industry. TAPPI. 1988. Amount of lignin, TAPPI Standard Test Method. TAPPI. T 222 om-88.

Technical Association of the Pulp and Paper Industry. TAPPI. 2015. Holocellulose in Wood, TAPPI Standard Test Method. TAPPI. T9 wd-75.

Technical Association of the Pulp and Paper Industry. TAPPI. 2006. Kappa Number of Pulp, TAPPI Standard Test Method. TAPPI T 236om-06.

Yadav, S.; Gupta, G.; Bhatnagar, R. 2015. A review on composition and properties of bagasse fibers. International Journal of Scientific \& Engineering Research 6(5): 143-147. 